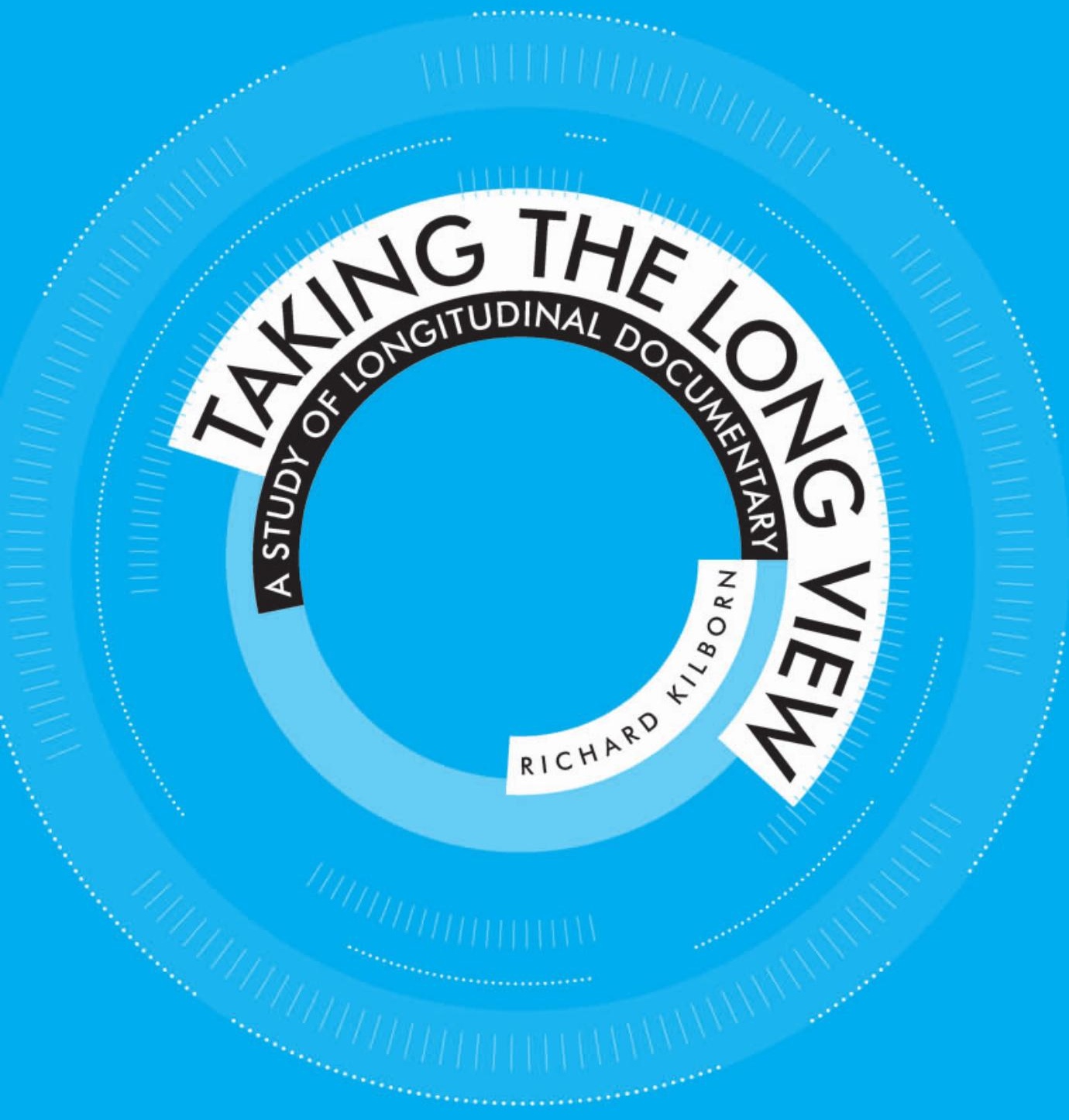




\section{Taking the long view}

\section{MANCHESTER 1824}

Manchester University Press 
Richard Kilborn - 9781847793171

Downloaded from manchesterhive.com at 04/26/2023 03:09:41PM 


\section{Taking the long view A study of \\ longitudinal documentary}

\section{Richard Kilborn}

Manchester University Press

Manchester and New York

distributed in the United States exclusively

by Palgrave Macmillan 
Copyright $($ ) Richard Kilborn 2010

The right of Richard Kilborn to be identified as the author of this work has been asserted by him in accordance with the Copyright, Designs and Patents Act 1988.

Published by Manchester University Press

Oxford Road, Manchester M13 9NR, UK

and Room 400, 175 Fifth Avenue, New York, NY 10010, USA

www.manchesteruniversitypress.co.uk

Distributed in the United States exclusively by

Palgrave Macmillan, 175 Fifth Avenue, New York,

NY 10010, USA

Distributed in Canada exclusively by

UBC Press, University of British Columbia, 2029 West Mall,

Vancouver, BC, Canada V6T 1Z2

British Library Cataloguing-in-Publication Data

A catalogue record for this book is available from the British Library

Library of Congress Cataloging-in-Publication Data applied for

ISBN 9780719078644 hardback

ISBN 9780719078651 paperback

First published 2010

The publisher has no responsibility for the persistence or accuracy of URLs for any external or third-party internet websites referred to in this book, and does not guarantee that any content on such websites is, or will remain, accurate or appropriate.

Typeset by Special Edition Pre-press Services

www.special-edition.co.uk

Printed in Great Britain

by MPG Books Group, UK 